\title{
Male Teachers Attrition: Causes and Consequences in Ebonyi State Public Primary and Secondary Schools
}

\author{
Paul Nwakpa \\ Department of Educational Foundations \\ Faculty of Education, Ebonyi State University \\ Abakaliki, Nigeria \\ Email: bropaulnwaoo [AT] gmail.com
}

\begin{abstract}
---
Objectives: To identify the causes and consequences of male teachers attrition in primary and secondary school in Ebonyi State, and to recommend strategies for adoption.

Methods/Statistical Analysis: Descriptive survey design was adopted. 300 respondents were used. A 30 item questionnaire was used for data collection. The instrument was validated by three experts. The reliability index of the instrument was 0.78. The instrument was administered on the respondents by the researcher and nine research assistants. Data collected were analyzed using mean scores and decision rule of 2.50 .

Findings: it was found in table one that low level of educational qualification, low salaries, poor working condition, poor motivation, lack of job satisfaction, poor treatment of teachers contributed to male teachers attrition in primary and secondary schools in Ebonyi state. The above findings agree with ${ }^{1}$ who opined that low salaries, low educational qualification of male teachers help in male teachers attrition in school.

Poor working condition found in this study agrees with ${ }^{2}$ who observed that poor working condition helps in male teachers attrition in schools. This study found that lack of job satisfaction makes male teachers to drop from teachers is in agreement with ${ }^{3}$ observation that lack of job satisfaction makes male teachers to leave teaching profession. The uniqueness of the findings of this study lies in the strategies such as giving male students scholarship to read education, giving teachers hazard allowance, extending car loans to teachers, among others. Adopting all the suggested strategies would in fact add prestige to teaching profession and attract the best brains to teaching profession.
\end{abstract}

Application/improvements: Adoption of the findings of this study will be the best approach to solve problems facing teaching and learning in primary and secondary schools in Ebonyi State.

Keywords---- Male Teachers, Attrition, Causes, Strategies.

\section{INTRODUCTION}

Education is seen as a catalyst for change and an instrument for social, political and economical development. Education is very important to man as life itself because it is the skilful process of bringing out the innate potentials in individuals. Education helps to develop human endowments and aims at the development of the entire personality of an individual $^{4}$. Education equips an individual to participate in the social life of their community and to make their contributions towards the development of their society. Education means the influence of the environment upon the individual to produce a permanent change in the habits of behaviors, thought and attitudes of individuals ${ }^{5}$.

Education can be beneficial to the members of the society in various ways: through education peoples culture can be transmitted from generation to generation, it enlightens the citizens, it supplies manpower for national development; it informs individuals of their right, privileges, duties and responsibilities; it empowers individuals to have a successful and fulfilled life in the society thereby contributing positively towards technological, scientifically, cultural, political, social and economic development of the nation.

The inception of western education in Nigeria in 1842 brought about the needed change in education in Nigeria. When the missionaries introduced education in Nigeria, it was very prestigious to be a teacher. Teachers were highly respected and well esteemed in the society. Thus, most people wished to be teachers.

Males were exposed to teaching in most of the mission schools because; the missionaries used them as messengers, interpreters, catechists and evangelists which exposed them to interacting with people. Western education was first made available to the males and this brought the needed change at that time. 
The effect of male teaching that time were marked by high rate of discipline, respect for elders; good academic performance in schools, there was dedication to duty, students were studious and obedient and they showed high commitment to their studies.

However, the education of the female was not emphasized.

Females were at that time culturally sentenced to domestic chores which were looked upon as their main office ${ }^{6}$. Presently in Ebonyi State, the reverse is the case; there is a great turn around. The system is now witnessing low male enrolment in teaching as a result of change in value. The females are preferred to schooling to males as noticed by ${ }^{7}$ in the Faculty of Education Ebonyi State University, Abakaliki. The males prefer studying other courses in school and going to learn trade and crafts. Since teaching especially at these levels of education (Primary and Secondary) Males being more materialistic prefer joining business circle to make quick money syndrome in our society is orchestrated by the attachment associated with wealth no matter the means by the society nowadays.

The females seem to have taken over teaching in various schools hence teaching is referred to as females' job. It has been observed that, leaving teaching alone in the hands of the females has been marred by so many ills such as; indiscipline, truancy, poor academic performance, lack of respect, lateness to schools, lack of commitment to studies, students' lack of focus and interest.

\section{CAUSES OF MALE ATTRITION IN TEACHING}

Many numbers of Male teachers entered into teaching with low level of educational qualification, some of them furthered their education and got higher degrees and left teaching. While others who could not further their education joined business or other endeavors to survive due to low income from teaching.

${ }^{1}$ further asserted that not only that teachers are poorly paid, even the meager salaries are not often times forth coming. Teachers in Nigeria are the least paid among other professions like medicine, engineering and law. A lot of disparities do exist in terms of salaries when compared to other professions. ${ }^{8}$ opined that poor salary of teachers scare the males from joining teaching. A lot of male teachers could not cope with what they earn as their salaries at the end of the month. The male teachers are mostly affected because they are the bread winners hence they cannot fend for their families and meet up with other responsibilities such men are regarded as failures in the society.

Another factor is that of work load. The work load of teachers is grossly very heavy. Teachers work round the clock, as the work does not end at the school level, their work extends to their private homes coupled with large student population. A walk to schools will tell you that teachers work in a very unconducive environment in all ramifications. This is a job that even at the apex of a teacher, he is not sure of driving a car or housing himself in his own house, and worse still his retirement benefits what a hopeless job!

\section{CONSEQUENCES OF MALE TEACHERS' ATTRITION FROM SCHOOLS IN EBONYI} STATE

There are lots of indiscipline ranging from cultism, stealing, examination malpractices, truancy. Their exit affected teaching of key subjects that are male dominated like physics, Chemistry and Mathematics ${ }^{10}$. The exit of male teachers affects the general character control in students especially boys because they have physical strength and are strong disciplinarians who can flog, punish and change behaviours of the students especially the male students ${ }^{11}$. The above consequence leads to urgent solutions. Some of the needed urgent solutions are: The teachers' salaries should be the same with that of their counterparts in medicine, politics, law and other professions. Admissions should be given to male students especially in the areas of Mathematics, Physics and Chemistry. The work load of teachers needs to be reduced by employing more number of teachers to match with the number of students. There should be adequate improvement in the teachers' condition of service. The retirement entitlements of teachers should be paid immediately on retirement without unnecessary bottlenecks. Government should award scholarships to males going for education programme in tertiary educational institutions. Political appointments should be extended to teachers in the society. More male teachers should be recruited into teaching profession. Car loans should be extended to teachers and the principals of schools should be assigned to official cars and official residence. With the above measures on ground, the image of Nigerian teachers will be raised and males will struggle to join teaching profession, and best brains instead of push over will attracted to faculty of education. This situation requires urgent attention, hence this study causes and consequences of male teachers' attrition in both primary and public secondary schools in Ebonyi State.

\section{RESEARCH QUESTIONS}

Three research questions guided this study.

1. What are the causes of male teachers' attrition in primary and secondary schools in Ebonyi State?

2. What are the consequences of male teachers' attrition in primary and secondary schools in Ebonyi State?

3. What strategies could be adopted to prevent male teachers' attrition in primary and secondary schools in Ebonyi State? 


\section{METHOD}

Descriptive survey design was adopted in the study. The population of the study was 300 male teachers drawn from both primary and secondary schools in Ebonyi State. Simple random sampling was used to draw the 300 respondents out of 3000 male teachers used in collecting data for the study. A structured questionnaire constructed by the researcher entitled, 'causes' and consequences of male teachers' attrition in primary and secondary schools in Ebonyi State' (CCMTAPSSES). The questionnaire has two parts. A and B. Part A sought information on the personal data of the respondents while Part B with three Sections, 1,2 and 3 sought information on the causes, consequences and strategies to be adopted in order to solve the identified problems.

The instrument contained a total of 30 items. The respond mode adopted in the questionnaire was four Point Scale of strongly Agree (SA) Agree (A) Disagree (D) and Strongly Disagree (SD). The instrument was face validated by three experts; one from Measurement and Evaluation of the Department of Science Education, and two from the Department of Educational Foundations all of Ebonyi State University, Abakaliki.

The reliability of the instrument was established using test retest procedure. The two tests were administered within three weeks on 20 male teachers who were not Part of the sample of the study. Pearson product moment correlation coefficient value of 0.78 was obtained.

The questionnaire was administered to the respondents by the researcher with the help of nine research assistants. All copies of the questionnaire (300) distributed were collected back because of on the spot administration and collection technique used. Data collected were analyzed using Mean Scores. The four point mode used adopted the Mean of 2.50 and above as accepting Mean of the items while a Mean of less than 2.50 was rejected.

\section{Research Question One:}

\section{RESULTS}

What are the causes of male teachers' attrition in primary and secondary schools in Ebonyi State?

Results for this research question were shown in table 1.

Data in table 1 showed that all the items attracted Mean responses of well above 2.50 with the grand mean of 3.89 indicated agreement with the stated items as the causes of male teachers' attrition in both primary and secondary school in Ebonyi State.

\section{Research Question Two:}

What are the consequences of male teachers' attrition in primary and Secondary schools in Ebonyi State?

Results for research question two were shown in table 2

Data in table 2 showed that all items attracted positive responses with Mean Scores well above 2.50. The grand mean of 3.6 is an indication that the respondents agreed to the stated items as the consequences of male teachers' attrition in Primary and Secondary schools in Ebonyi State.

\section{Research Question Three:}

What strategies could be adopted to prevent male teachers' attrition in primary and secondary schools in Ebonyi State?

Data in table 3 showed that the respondents reacted positively to all the items with mean scores well above 2.50 . The grand mean of 3.81 indicated that the respondents agreed to the suggested strategies as measures to prevent male teachers' attrition in primary and secondary schools in Ebonyi State.

\section{DISCUSSION}

The results as presented in table 1 showed that all the respondents agreed to all the items as the major causes of male teachers' attrition in primary and secondary schools in Ebonyi State. The findings agree with the opinion of ${ }^{1}$ who opined that low Salaries, low educational qualification of male teachers' attrition in schools. Some other findings of the study also confirmed ${ }^{3}$ observation that lack of job satisfaction and low esteem of teachers, and also ${ }^{2}$ observed that poor working condition, low Socio-economic Status and lack of motivation of teachers' attrition in primary and secondary schools in Ebonyi State.

In relation to the consequences of male teachers attrition in primary and secondary schools in Ebonyi state as presented in table 2 results showed that the respondents agreed to all the items as the consequences of male teachers' attrition in primary and secondary schools in Ebonyi State. The findings of this study agree with the observation of ${ }^{10}$ "Poor academic achievement" a barrier to male students choosing teaching as a career" and high rate of indiscipline.

As regards the strategies to be adopted to solve the problem of male teachers' attrition from teaching, the respondents also agreed to all the listed items as the solutions to male teachers' attrition in primary and secondary schools in Ebonyi State which include; working condition of teachers to be revamped like other professions, teachers' salaries to be increased, recruitment of more male teachers and teachers to be given political appointments. 


\section{CONCLUSION}

The results of the study showed the different causes, consequences and strategies to male teachers' attrition in primary and secondary schools in Ebonyi State. This actually shows the importance of male teachers in the education systems. They enforce higher rate of discipline, among students, they ensure security of both students and school property. Thus government should see that male teachers are encouraged to remain in teaching profession as their absence might cause serious barrier to academic productivity and achievement.

\section{RECOMMENDATION}

In order to put an end to male teachers' attrition in both primary and secondary schools in Ebonyi State, the following should be done urgently.

1. Teachers' salaries should be increased.

2. Teachers should be promoted at the right time.

3. Teachers' professional body should regulate the entry into teaching profession.

4. Those who did not study education should not be employed to teach.

5. Teachers should be given appointment by the government.

6. Government should make teaching profession to be at the same level with other professions.

7. Working condition of teachers should be enhanced.

8. Teachers' retirement benefit should be ensured.

9. Teachers should be recruitment yearly to replace those going on retirement in order to avoid shortage of teachers.

10. Scholarship should be given to those wishing to study education.

\section{REFERENCES}

1. Ofojebe PN. Guide to Teaching Progress, New Age Publications; Ugep, 2006.

2. Nnadozie DA. Teacher education and Nigeria in the $21^{\text {st }}$ Century. Proceedings of $8^{\text {th }}$ conference of the school of education, College of Education, Ojo, 2005, pp. 100-110.

3. Jagaba OP. Job satisfaction in schools. XYZ printing press, Abakaliki, 2008.

4. Isichei FM, Olufomobi OO. An Introduction to Philosophical foundations of education, $1^{\text {st }}$ edn. Almarks Publishers Ltd: Lagos, 2005.

5. Tompson SO. Principles of Administration, Omego Printing Press; Abakaliki, 1981

6. Okolo AN. The impact of tradition on Nsukka women participation in Socio-political activities. International journal of Arts and Technology Education 2001, 1 (1) 18-22.

7. Nwakpa NP. Educational Administration, Genesis Communications; Onitsha, 2010.

8. Azubuike NO. Conditions of service for teachers in Nigeria. $2^{\text {nd }}$ edn. West and Solomon Publishers: Onitsha, 2006.

9. Ajaegbo NA. The teaching profession, In: Sociology of Education for Colleges and Universities, S.O Igboabuchi (ed.), Lined Publishers; Onitsha 2010, pp. 66-95.

10. Okebukola P. Quality teacher education for future: Directions for Research. The Nigeria Teachers Education Journal, NCCE, July, 8 (1), pp. 150-168. 


\section{LIST OF TABLES}

Table 1: Mean ratings of the respondents on the causes of male teachers' attrition in primary and secondary schools in Ebonyi State.

The following are the causes of male teachers' attrition in primary and secondary schools in Ebonyi State.

\begin{tabular}{clll}
\hline S/N & ITEMS & $\mathbf{X}$ & DECISION \\
\hline 1. & Low level of educational qualification & 3.79 & Agree \\
2. & Abandonment of teaching for other professions & & Agree \\
3. & Low Salaries & 3.68 & Agree \\
4. & Heavy work load & 4.00 & Agree \\
5. & Poor working condition & 3.55 & Agree \\
6. & Low Socio-economic Status & 4.00 & Agree \\
7. & Poor Motivation. incentives & 4.00 & Agree \\
8. & Lack of job Satisfaction & 3.95 & Agree \\
9. & Poor societal esteem & 3.88 & Agree \\
10. & Poor treatment of teachers & 3.74 & Agree \\
& Total & $\mathbf{3 8 . 5 6}$ & Agree \\
& Grand Mean & $\mathbf{3 . 8 6}$ & Agree \\
\hline
\end{tabular}

Table 2: Mean ratings of the respondents on the consequences of male teachers' attrition in primary and secondary schools in Ebonyi State

The following are the consequences of male teachers' attrition in primary and secondary schools in Ebonyi State.

\begin{tabular}{clll}
\hline S/N & ITEMS & $\mathbf{X}$ & DECISION \\
\hline 1. & High rate of indiscipline & 3.61 & Agree \\
2. & High rate of insecurity & 3.67 & Agree \\
3. & Low Productivity & 3.88 & Agree \\
4. & Barrier to choosing teaching as a profession & 3.71 & Agree \\
5. & Poor academic achievement & 3.92 & Agree \\
6. & Poor teaching physics Mathematics and Chemistry & 4.00 & Agree \\
7. & Shortage of teachers & 3.48 & Agree \\
8. & Gender inequality in teaching profession & 3.67 & Agree \\
9. & It leads to brain drain & 3.89 & Agree \\
10. & It leads to employment of non professionals in teaching. & 3.83 & Agree \\
& Teaching & 3.83 & Agree \\
& Total & $\mathbf{3 7 . 6 6}$ & Agree \\
& Grand $\mathbf{x}$ & $\mathbf{3 . 7 7}$ & Agree \\
\hline
\end{tabular}


Table 3: Mean ratings of the respondents on the strategies to be adopted to prevent male teachers' attrition in primary and secondary schools in Ebonyi State.

\begin{tabular}{|c|c|c|c|}
\hline $\mathbf{S} / \mathbf{N}$ & ITEMS & $\mathbf{X}$ & DECISION \\
\hline 1. & $\begin{array}{l}\text { Male students who wants to study education should be given } \\
\text { admission in there are of choice }\end{array}$ & 3.15 & Agree \\
\hline 2. & $\begin{array}{l}\text { Teachers' Salaries should be as those in medicine or Law or army } \\
\text { etc. }\end{array}$ & 4.00 & Agree \\
\hline 3. & $\begin{array}{l}\text { Government should give scholarship to all Male Students studying } \\
\text { education in tertiary institutions. }\end{array}$ & 3.61 & Agree \\
\hline 4. & Male teachers should be given adequate motivation & 4.00 & Agree \\
\hline 5. & Recruitment of more Male teachers. & 3.07 & Agree \\
\hline 6. & Teachers should be part of Political appointments. & 3.81 & Agree \\
\hline 7. & $\begin{array}{l}\text { Working Conditions of teachers should be revamped like other } \\
\text { professions. }\end{array}$ & 4.00 & Agree \\
\hline 8. & Car loans should be extended to teachers & 3.72 & Agree \\
\hline 9. & $\begin{array}{l}\text { Principals of schools should be provided with official cars and } \\
\text { drivers }\end{array}$ & 4.00 & Agree \\
\hline \multirow[t]{3}{*}{10.} & Teachers should be entitled to hazard allowance & 3.83 & Agree \\
\hline & Total & 37.19 & Agree \\
\hline & Grand Mean $(x)-$ & 3.72 & Agree \\
\hline
\end{tabular}

